\title{
Unilateral Viable Twin Tubal Ectopic Pregnancy: A Case Report
}

Jawaher alsahabi ${ }^{1}$, Haya aljurayfani ${ }^{2}$, Afaf Felemban $^{3 *}$, Fahad alsalman $^{1}$, Samar Hassan $^{1}$

${ }^{1}$ Associate Consultant, Department of Obstetrics and Gynecology, NGHA, Riyadh, Saudi Arabia

${ }^{2}$ Resident, Department of Obstetrics and Gynecology, NGHA, Riyadh, Saudi Arabia

${ }^{3}$ Consultant reproductive endocrinology and IVF, Department of Obstetrics and Gynecology, NGHA, Riyadh, Saudi Arabia

*Corresponding author: Afaf Felemban, Consultant reproductive endocrinology and IVF, Department of Obstetrics and Gynecology, NGHA, Riyadh, Saudi Arabia.

Received date: December 12, 2019; Accepted date: January 07, 2020; Published date: January 23, 2020

Citation: Jawaher A, Haya A, Afaf F, Fahad A, Samar H(2020) Unilateral Viable Twin Tubal Ectopic Pregnancy: A Case Report. J Clinical Research and Reports, 1(1); DOI:10.31579/jcrr.2020/008

Copyright: () 2020 Afaf Felemban, This is an open access article distributed under the Creative Commons Attribution License, which permits unrestricted use, distribution, and reproduction in any medium, provided the original work is properly cited.

Abstract
Unilateral ectopic twin is a rare condition with only a few cases of viable ectopic twins reported. We report a 41
year- old, Gravida 6 Para 5 at 6 weeks gestation, presented to the Emergency Department with complaint of
lower abdominal pain and vaginal spotting. Pelvic ultrasound showed twins with positive fetal heart beats in
the right tube. Laparoscopic salpingectomy was performed to remove to fetus.
Conclusion
Viable ectopic pregnancy is a life threatening condition and can be diagnosed with ultrasound. Surgical removal
is the standard treatment option.
Key words: ectopic pregnancy; twins, tubal pregnancy, positive fetal heart

\section{Introduction}

Ectopic pregnancy is a life-threatening condition and is still considered as one of the most important causes of maternal mortality [1]. Ectopic twins is a very rare type of ectopic pregnancy. Incidence of twin tubal pregnancy is 1 out of 725-1580 tubal pregnancy and 1in 200000 pregnancies. Very limited number of viable twin ectopic pregnancies have been reported in the literature Spontaneous twin tubal ectopic pregnancy is even rarer with reported incidence of 1 in every 125,000 spontaneous pregnancies. 24,5 In literature review there are more than 100 cases of twin tubal pregnancy have been reported, there are only a few cases with documented fetal heart motions in both embryos or fetuses. 6

Case report

A 41 year-old Gravida 6 Para 5, presented to the emergency department of King abdulaziz Medical City- Riyadh, Saudi Arabia at 6weeks of gestations with Symptoms of lower abdominal pain and vaginal spotting. Current Pregnancy resulted from induction of ovulation. There were no histories of any major medical or surgical illness in the past.Her vital signs were stable. Abdominal examination revealed no tenderness or rebound tenderness on palpation and deep pression, vaginal examination did not find ervical motion tenderness. Her blook work showed BHCG of 13231, other investigations were within normal. Altraound of trans-abdominal (Fig:1) and trans-vaginal scan showed right-adnexal viable twin pregnancy with two yolk sacs and two pulsations, measuring $5.4 \mathrm{x} 4.1 \mathrm{~cm}$. The patient was diagnosed as ectopic tubal twin pregnancies. The patient was taken for Emergency for laparoscopic salpingectomy. Intraoperatively, there was moderate hemoperitoneum, right sided salpingectomy was done. The patient did well postoperatively and was discharged on the 3rd day. The histopathological examinations confirmed the Diagnosis (fallopian tube with intraluminal trophoblastic villi and fetal tissue). 


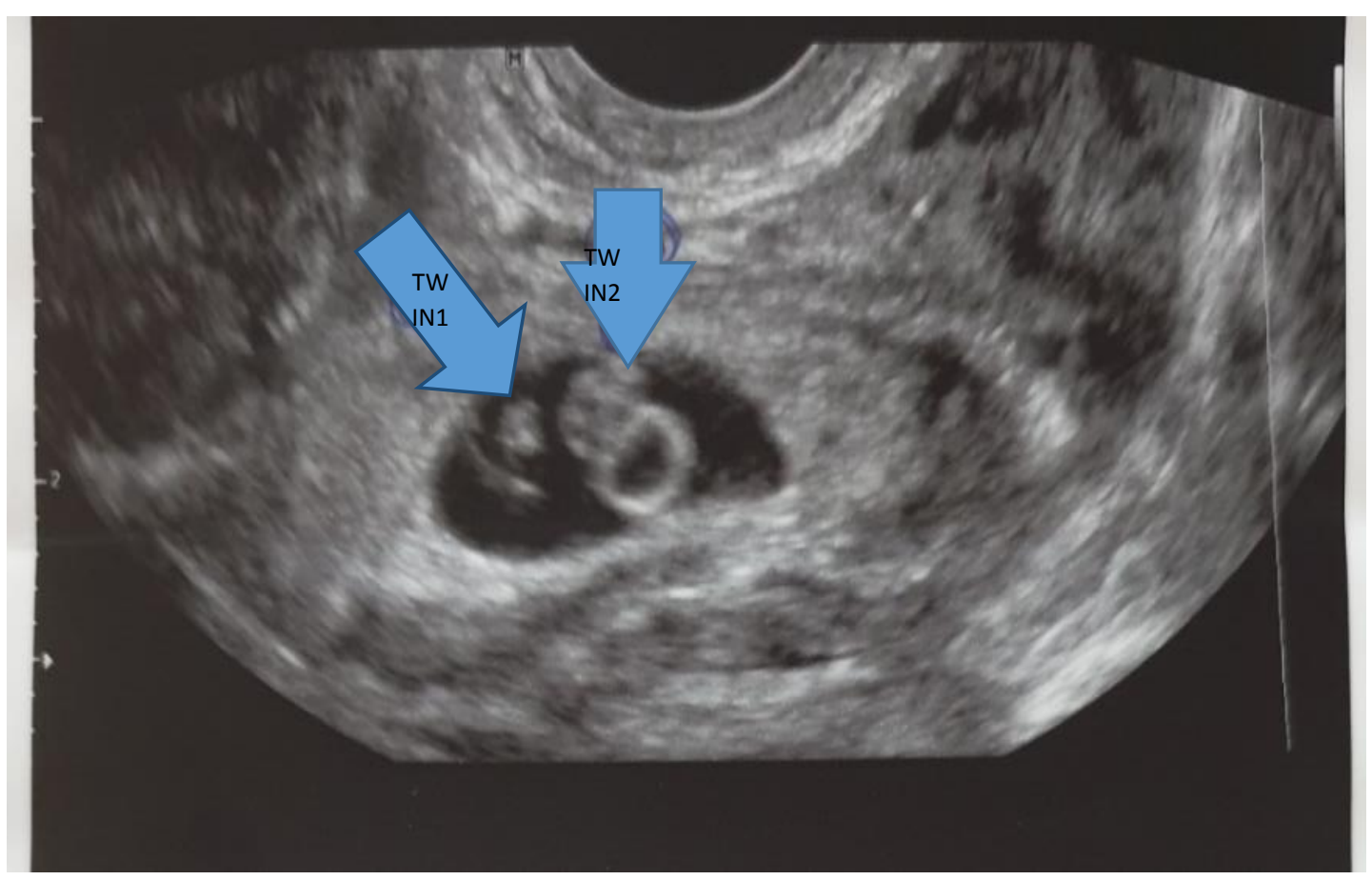

Figure: 1

\section{Discussion}

(This part needs to be rewritten again. Sensitive methods for pregnancy diagnosis together with high-resolution transvaginal sonography mean that ectopic pregnancy can often be diagnosed at an early stable stage.7 Several factors are increased the risk of ectopic pregnancy. Pelvic inflammatory disease is associated with the greatest increase in risk, but other associated factors include operative trauma, congenital anomalies, tumors, adhesions, and advancing maternal age 9 this case has several differences from other cases of unilateral live twin tubal pregnancies. First, the patient conceived after ovulation induction only whereas most cases were associated with ART and other risk factors. Second, each fetus in the twin pregnancy had a yolk sac and fetal heart activity.

Patient presented with high level of bhcg, that may raise the concern of heterotopic pregnancy or twins pregnancy which might be overlooked as singleton viable pregnancy, for that by reporting such cases it will raise the knowledge of possible twins ectopic pregnancy in high level BHCG then it may help considering appropriate intervention and follow up accordingly.

\section{Conclusion}

Viable ectopic pregnancy is a life threatening with changing diagnosis surgical treatment is usual approach for management.

\section{References}

1. Hanchate V, Garg A, Sheth R, Rao J, Jadhav PJ et al (2002) Transvaginal sonographic diagnosis of live monochorionic twin ectopic pregnancy. J Clin Ultrasound. 30:52-56.
2. Dejan Samardzic, Claudia JK, Sabrina VP (2014) Live Monochorionic Adnexal Twin Ectopic Pregnancy Ultrasound Quarterly \& Volume 30, Number 3.

3. Svirsky R, Maymon R, Vaknin Z, Mendlovic S, Weissman A et al (2010) Twin tubal pregnancy: a rising complication? .Fertil Steril. 2010 Oct;94(5):1910.e13-6.

4. Murat Dede, Kazım Gezgin, Müfit Yenen, Mustafa Ulubay, Salih Kozan et al (2008) UNILATERAL TUBAL ECTOPIC TWIN PREGNANCY Taiwan J Obstet Gynecol • June. Vol 47; No 2

5. Chang-Ihll Kim, Tae-Yeem Lee, Sung-Taek Park, Hong-Bae Kim, Sung-Ho Park (2018) A rare case of spontaneous live unilateral twin tubal pregnancy with both fetuses presenting with heart activities and a literature review. Published online 2018 Mar 2.

6. Sujin Kanokpongsakdi, Vitaya Titapant (2010) Pre-operative Diagnosis of Alive Twin Tubal Pregnancy Siriraj Med J 2010;62:71-72

7. Murat Dede, Kazım Gezginç, Müfit Yenen, Mustafa Ulubay et al (2008) UNILATERAL TUBAL ECTOPIC TWIN PREGNANCY

Taiwan J Obstet Gynecol • June 2008; Vol 47. No 2.

8. SD Sur, BChir(Cantab), K Reddy (2005) MRCOG FRCS Spontaneous unilateral tubal twin pregnancy. J R Soc Med. 2005 Jun; 98(6): 276.

9. Charles JRolle, Clifford YWai, Roger Bawdon, Rigoberto SR, Barbara Hoffman (2006)

10. Unilateral Twin Ectopic Pregnancy in a Patient With a History of Multiple Sexually Transmitted Infections Infect Dis Obstet Gynecol. 2006; 10306. 
This work is licensed under Creative Commons Attribution 4.0 License

\section{To Submit Your Article Click Here: Submit Article}

DOI:10.31579/jcrr.2020/008

\footnotetext{
Ready to submit your research? Choose Auctores and benefit from:

* fast, convenient online submission

* rigorous peer review by experienced research in your field

* rapid publication on acceptance

* authors retain copyrights

* unique DOI for all articles

* immediate, unrestricted online access
}

At Auctores, research is always in progress.

Learn more https://www.auctoresonline.org/journals/journal-of-clinicalresearch-and-reports 